\title{
HUBUNGAN DERAJAT PENYAKIT HIPERTENSI DENGAN TINGKAT KECEMASAN PADA KELOMPOK LANJUT USIA DI WILAYAH KERJA PUSKESMAS KAHAKITANG KECAMATAN TATOARENG
}

\author{
Femmy Lumi 1), Maria Terok ${ }^{2)}$, Freyjer Budiman ${ }^{3)}$ \\ 1),2),3) Jurusan Keperawatan Poltekkes Kemenkes Manado \\ email: femmy_lumi@yahoo.com
}

\begin{abstract}
Hypertension is a disease that is often experienced by the elderly and it becomes a global health issue that requires special attention because it can lead to major deaths in developed countries as well as developing countries. One of the risk factors of hypertension is anxiety. Anxiety is caused due to various circumstances such as worry, anxiety, fear, discomfort accompanied by various physical complaints and health problems. The purpose of this study was to analyze the relationship of degree of hypertension with anxiety level in elderly group. The type of this research is analytical study with cross sectional, that have 95 population elderly and become 67 elder total sampel of characteristic inclusion. Data were collected using questionnaire and analyzed by using chi-square test. The Results Discussion have Degrees of hypertensive disease in elderly individuals (36\%) were at mild and severe levels with moderate anxiety level in elderly (44.78\%). The result of chi-square test using SPSS, $P=0,000$ which is smaller than $\alpha=0,05$ meaning that there is a very significant relation on degree of hypertension with anxiety level in elderly group. Based on the results of research, the nurse will improve the elderly health by maintaining the promotion effort in the form of health counseling to the elderly group, empowering the elderly group and maintaining the psychological condition.
\end{abstract}

Keywords: Degrees of Hypertension, Level of Anxiety

Abstrak

Salah satu indikasi pembangunan kesehatan adalah terlihat dari umur harapan hidup, peningkatan usia harapan hidup dan penurunan angka fertilitas mengakibatkan populasi penduduk lanjut usia meningkat. Lansia senang mengkonsumsi makanan yang berpotensi menyebabkan tekanan darah meningkat dan berdampak terjadi penyakit tidak menular seperti penyakit hipertensi, penyakit hipertensi di Indonesia 15,2\% di Sulut, di Puskesmas Kahakitang 14\%. Hal ini menunjukan angka penyakit hipertensi sangat tinggi dan bagi lansia dapat menyebabkan kecemasan jika penyakit hipertensi tidak ditangani dengan baik. Tujuan penelitian ini adalah untuk menganalisis hubungan derajat penyakit hipertensi dengan tingkat kecemasan pada kelompok lanjut usia. Jenis Penelitian ini adalah Analitik dengan pendekatan Cross Sectional dengan jumlah populasi 95 lanjut usia dengan teknik total sampel yang memenuhi kriteria inklusi menjadi 67 responden. Pengumpulan data menggunakan kuesioner dan dianalisis dengan menggunakan uji chi-square. Hasil Penilitian ditemukan Derajat Penyakit hipertensi pada lanjut usia masing-masing $(36 \%)$ berada pada tingkat ringan dan berat dengan tingkat kecemasan sedang pada lanjut usia (44,78\%). Hasil uji chi-square menggunakan SPSS ditemukan $P=0,000$ yang lebih kecil dari $\alpha=0,05$ yang berarti bahwa ada hubungan yang sangat bermakna pada penyakit hipertensi dengan tingkat kecemasan pada lanjut usia. Berdasarkan penelitian ini perawat akan melakukan peningkatan kesehatan lanjut usia dengan mempertahankan usaha promosi berupa penyuluhan kesehatan terhadap kelompok lanjut usia, melakukan pemberdayaan kelompok lanjut usia dan menjaga keadaan psikologisnya.

Kata Kunci : Derajat Penyakit Hipertensi, Tingkat Kecemasan

\section{LATAR BELAKANG}

Salah satu indikasi keberhasilan pembangunan kesehatan terlihat dari Umur Harapan Hidup (UHH), angka harapan hidup $(\mathrm{AHH})$. Peningkatan usia harapan hidup dan penurunan angka fertilitas mengakibatkan populasi penduduk lanjut usia meningkat. World Health Organization (WHO) memperkirakan akan terjadi peningkatan proporsi lanjut usia didunia dari $7 \%$ pada tahun 2020 meningkat jadi 23\% pada tahun 2025.

Penderita hipertensi menurut survey dilakukan oleh World Health Organization (WHO) dalam Siringoringo (2013), mencatat satu miliar orang di dunia menderita penyakit hipertensi.
Berdasarkan laporan Perserikatan Bangsa-Bangsa 2011, tahun 2000-2005 $\mathrm{UHH}$. 66,4 tahun dengan persentase populasi lanjut usia tahun 2000 adalah $7,74 \%$, angka ini akan meningkat pada tahun 2045-2050 yang diperkirakan UHH menjadi 77,6 tahun dengan persentase populasi lanjut usia tahun 2045 adalah $28,68 \%$.

Laporan Badan Pusat Statistik (BPS) di Indonesia terjadi peningkatan UHH. Tahun $2000 \mathrm{UHH}$ di Indonesia 64,5 tahun dengan persentase populasi lanjut usia $7,18 \%$. Angka ini meningkat menjadi 69,43 tahun pada tahun 2010 persentase populasi lanjut usia 7,56\% kemudian tahun 2011 menjadi 69,65 tahun dengan persentase populasi lanjut usia adalah 7,58\%. Hasil Riset Kesehatan Dasar 
(Riskesdas) 2013, prevalensi hipertensi penduduk berumur 18 tahun ke atas pada tahun 2013 sebesar 25,8\%. Data tertinggi di Bangka Belitung $30,9 \%$, diikuti Kalimantan Selatan 30,8\%, Kalimantan Timur 29,6\%, Jawa Barat 29,4\% dan Gorontalo 29,4\%. Provinsi Sulawesi Utara mencapai 15,2\%.

$$
\text { Data diperoleh di Wilayah Kerja }
$$

Puskesmas Kahakitang Kecamatan Tatoareng tahun 2016 terdapat 10 penyakit terbanyak yaitu ISPA 40\%; 816 Orang, Gastritis 16\%; 324 orang, Hipertensi 14\%; 285 orang, Malaria 7\%; 149 orang, Obs Febris 7\%; 142 orang, Dermatitis 6\%; 116 orang, Diare 3\%; 72 orang, Artritis 3\%; 69 orang, Abses 2\%; 48 orang, ISK 2\%; 37 orang. (sumber laporan LB 1 PKM Kahakitang 2016). Hipertensi tertinggi ke 3 dari 10 penyakit yang dikaji bulan Februari 2016 sampai Oktober 2017 berjumlah 285 orang, hipertensi ini terjadi karena pola makan yang tidak teratur serta kebiasaan masyarakat setempat yang sering mengkonsumsi ikan garam dengan porsi yang banyak sehingga menyebabkan tekanan darah meningkat, sehingga dengan adanya peningkatan tekanan darah dapat menyebabkan kecemasan pada lanjut usia, dalam penelitian ini total sampel berjumlah 67 orang terdiri dari 8 orang laki-laki dan 59 orang perempuan.

Hasil survei awal pada tanggal 8 Januari 2018 saat wawancara pada 5 orang pasien lanjut usia yang datang berobat ke Puskesmas diketahui memiliki riwayat hipertensi dengan hasil pemeriksaan tekanan darah diatas $140 / 90 \mathrm{mmHg}$. Mereka merasa cemas karena penyakit hipertensi yang diderita sudah berlangsung lama, ada 2 orang diantara mereka yang pernah mengalami stroke. Petugas kesehatan mengatakan bahwa selama ini belum ada yang melakukan penelitian mengenai tingkat kecemasan pada pasien lansia dengan hipertensi.

Penelitian Kadek D. P, Okatiranti dan Tita P. N. (2016) dalam Jurnal IImu Keperawatan, vol. IV no.2 mengatakan ada hubungan antara tingkat kecemasan dengan kejadian hipertensi di Panti Sosial Tresna Werdha Senjarawi Bandung. Hasil penelitian Laksita D. I. (2016) ditemukan ada hubungan lama penyakit hipertensi dengan tingkat kecemasan pada lansia di Desa Praon Nusukan Surakarta. Demikian juga hasil penelitian Uswandari D. B. (2017) ditemukan ada hubungan antara kecemasan dengan kejadian hipertensi pada lansia di Panti Sosial Tresna werdha. Penelitian Siwu C. (2014) mengatakan ada hubungan penyakit hipertensi dengan tingkat kecemasan pada lanjut usia di Wilayah Kerja Puskesmas Minanga Kecamatan Malalayang.

\section{TINJAUAN PUSTAKA}

\section{A. Hipertensi}

1. Definisi hipertensi atau tekanan darah tinggi adalah peningkatan tekanan persistem pada pembuluh darah arteri, dimana tekanan darah sistolik di atas $140 \mathrm{mmHg}$ dan tekan diastolic diatas $90 \mathrm{mmHg}$ (LeMone, Burke,\& Baudoff, 2013; WHO, 2013)

Hipertensi adalah peningkatan tekanan darah dari arteri bersifat sistemik yang berlangsung terus-menerus dan terjadi dalam jangka waktu yang lama. Hipertensi adalah suatu kondisi saat nilai tekanan sistolik lebih tinggi dari $140 \mathrm{mmHg}$ atau nilai tekanan diastolic lebih tinggi dari $90 \mathrm{mmHg}$. untuk menegahkan diagnosis hipertensi perlu dilakukan pengukuran tekanan darah minimal 2 kali dengan jarak 1 minggu bila tekanan darah kurang dari 160/100 mmHg (Garnadi, 2012).

2. Etiologi

a. Hipertensi primer sekitar 95\% pasien merupakan hipertensi esensial (primer). Penyebab hipertensi ini masih belum diketahui, tetapi faktor genetik dan lingkungan diyakini menyebabkan hipertensi esensial (Weber dkk. 2014). Faktor lingkungan juga mempengaruhi terjadinya hipertensi : konsumsi garam berlebihan, obesitas dan aktifitas hidup yang tidak sehat (Robbins dkk. 2007).

b. Hipertensi sekunder sekitar 5\% pasien hipertensi (Weber dkk, 2014). Hipertensi sekunder terjadi karena konsumsi alkohol berlebihan, penyakit ginjal atau renalis, koarktasio (penyempitan) aorta serta sindrom cushing atau penyakit yang disebabkan oleh hormon kortisol yang abnormal.

3. Gejala klinis Hipertensi menurut WHO (2013) sebagian besar penderita hipertensi tidak merasakan gejala penyakit. Hipertensi terkadang menimbulkan gejala seperti sakit kepala, nafas pendek, pusing, nyeri dada, palpasi, dan epistaksis, gejala ini sering diketahui melalui pemeriksaan tekanan darah atau terjadi karena penyakit lain. 
a.Tabel 1. Klasifikasi Hipertensi tekanan darah menurut JNC VII 2003 (Garnadi, 2012)

Klasifikasi Sistolik $(\mathrm{mmHg}) \quad$ Diastolik $(\mathrm{mmHg})$

\begin{tabular}{lcc}
\hline Normal & $<120$ & $<80$ \\
Prehipertensi & $120-139$ & $80-90$ \\
Hipertensi tingkat I & $140-159$ & $90-99$ \\
Hipertensi tingkat II & $>160$ & $>100$ \\
\hline
\end{tabular}

b. Tabel 2. Klasifikasi hipertensi menurut World Health Organization (WHO) 1999

\begin{tabular}{lcc}
\hline \multicolumn{1}{c}{ Klasifikasi } & Sistolik $(\mathrm{mmHg})$ & Diastolik $(\mathrm{mmHg})$ \\
\hline Optimal & $<120$ & $<80$ \\
Normal & $<130$ & $<85$ \\
Normal-tinggi & $130-139$ & $85-89$ \\
Hipertensi derajat 1 (ringan) & $140-159$ & $90-99$ \\
Hipertensi derajat 2 (sedang) & $160-169$ & $100-109$ \\
Hipertensi derajat 3 (berat) & $\geq 180$ & $\geq 110$ \\
\hline
\end{tabular}

4. Patofisiologi Hipertensi

Menurut Wijaya (2013) proses terjadinya hipertensi adalah menurunnya tonus otot vaskuler merangsang saraf simpatis untuk diturunkan ke sel jugularis. Sel jugularis ini yang menyebabkan meningkatnya tekanan darah, jika sel jugularis ini diteruskan pada ginjal akan mempengaruhi ekskresi renin yang berkaitan dengan angiotensin, adanya perubahan angiostensin II berakibat terjadinya vasokontriksi pada pembuluh darah dan dapat meningkatkan hormon aldosteron yang menyebabkan retensi natrium. Hal tersebut akan berakibat pada peningkatan tekanan darah. Adanya peningkatan tekanan darah akan menimbulkan kerusakan pada organ seperti ginjal, mata jika hipertensi tidak ditangani dengan baik dapat mengakibatkan stroke, gagal jantung, gagal ginjal dan gangguan pengelihatan.

5. Komplikasi Hipertensi.

Wijaya (2013) mengatakan tekanan darah tinggi jika tidak ditangani atau diobati, dalam jangka panjang akan merusak pembuluh darah diseluruh tubuh, kompilkasi hipertensi: Stroke, retinopati diabetik, kerusakan ginjal, gagal ginjal dan penyempitan jantung koroner.

6. Pengendalian Hipertensi : gizi seimbang dan pembatasan gula, garam dan lemak (Dietary Approaches To Stop Hypertension), mempertahankan berat badan dan lingkar pinggang ideal, gaya hidup aktif serta olahraga teratur, berhenti merokok, membatasi konsumsi alkohol.

7. Pencegahan Hipertensi menurut pedoman teknis penemuan dan tatalaksana hipertensi (Kemenkes 2013) : diuretik, penyekat beta ( $\beta$-blockers), golongan penghambat Angiotensin Converting Enzyme (ACE) dan Angiotensin Receptor Bloker (ARB), golongan Calcium Channel Blokers (CCB), dan golongan Antihipertensi lain.

\section{Kecemasan}

1. Kecemasan adalah suatu perasaan subjektif mengenai ketegangan mental yang menggelisahkan sebagai reaksi umum dari ketidakmampuan mengatasi suatu masalah atau tidak adanya rasa aman. Perasaan yang tidak menentu tersebut pada umumnya tidak menyenangkan akan menimbulkan atau disertai perubahan fisiologis dan psikologis (Kholil L. R., 2010).

2. Predisposisi Kecemasan.menurut Kusnadi J. (2015)

Pandangan psikoanalitik, interpersonal, perilaku, kajian keluarga, biologis dan teori kognitif.

3. Presipitasi Kecemasan, menurut Kusnadi J. (2015)

Ancaman terhadap integritas diri dan terhadap sistem diri

4. Faktor Penyebab Kecemasan, menurut Kusnadi J. (2015)

Faktor biologis, psikologis dan sosial.

5. Tanda dan gejala kecemasan, rasa ketakutan yang difus, tidak menyenangkan dan samar-samar, disertai nyeri kepala, berkeringat, hipertensi, gelisah, tremor, gangguan lambung, diare, takut akan apa yang dipikirkannya, mudah tersinggung, merasa tegang, tidak tenang, gangguan pola tidur, dan gangguan kosentrasi.

Kecemasan juga memiliki karakteristik berupa perasaan takut dan kehati-hatian atau kewaspada-an yang tidak jelas, gejala kecemasan yang muncul dapat berbeda pada masing-masing orang. (Kaplan, 
Sadock, \& Grebb dalam Fitri F. \& Julianti W., 2007)

6. Klasifikasi Tingkat Kecemasan (Stuart \& Laraia 2005 dalam Eka A, 2010).

Kecemasan ringan (Mild anxiety), sedang

(Moderate anxiety), berat (Severe anxiety), dan panik.

7. Pengendalian kecemasan menurut Kusnadi J. (2015).

Relaksasi pernafasan, relaksasi untuk mengendalikan kecemasan dan stress.

\section{Lanjut Usia}

1. Lanjut usia menurut Undang-Undang Nomor 13 Tahun 1998 tentang kesejahteraan lanjut usia (lansia) adalah seseorang yang telah memasuki usia 60 tahun keatas. Lansia merupakan kelompok umur pada manusia yang telah memasuki tahapan akhir dari fase kehidupannya. Kelompok yang dikategorikan lansia ini akan terjadi suatu proses yang disebut Aging Process atau proses penuaan.

Lanjut usia adalah suatu proses menghilangnya secara perlahan-lahan kemampuan jaringan untuk memperbaiki diri dan mempertahan-kan struktur dan fungsi normalnya sehingga tidak dapat bertahan terhadap jejas (termasuk infeksi) dan memperbaiki kerusakan yang diderita (Wahyu dan Ina, 2009).

2. Batasan umur lanjut usia (WHO, 1999)

a. Usia pertengahan (middle age) antara usia 45 sampai 59 tahun

b. Lanjut usia (elderly) antara usia 60 sampai 74 tahun

c. Lanjut usia tua (old) antara usia 75 sampai 90 tahun

d. Usia sangat tua (very old) diatas usia 90 tahun

3. Tugas Perkembangan lanjut usia, menurut Burnside (1979), Duvall (1977) dan Havirghust (1953) dikutip oleh Potter dan Perry (2005).

Menyesuaikan terhadap penurunan kekuatan fisik dan kesehatan, terhadap masa pensiun dan penurunan pendapatan, dan terhadap kematian pasangan. Menerima diri sendiri sebagai individu lansia. Mempertahankan kepuasan pengaturan hidup. Mendefinisikan ulang hubungan dengan anak yang dewasa. Menentukan cara untuk mempertahankan kualitas hidup.

4. Perubahan yang terjadi pada lansia menurut Maryam Siti, R. dkk, (2008)
Perubahan fisik, kognitif, mental, spiritual, psikososial.

\section{Hipotesis Penelitian}

Ho : Tidak ada hubungan derajat penyakit hipertensi dengan tingkat kecemasan pada kelompok lanjut usia.

$\mathrm{Ha}$ : Ada hubungan derajat penyakit hipertensi dengan tingkat kecemasan pada kelompok lanjut usia

\section{METODE PENELITIAN}

Jenis penelitian yang digunakan adalah Analitik dengan pendekatan Cross Sectional artinya obyek diobservasi satu kali saja dan pengukuran menggunakan variabel independen dan dependen dilakukan pada saat penelitian. Hal ini dilakukan untuk mengetahui hubungan derajat penyakit hipertensi dengan tingkat kecemasan pada kelompok lanjut usia.

Penelitian dilakukan di Wilayah Kerja Puskesmas Kahakitang Kecamatan Tatoareng yaitu Kampung Kahakitang Sowaeng, Kampung Taleko Batusaiki, Kampung Dalako Bembanehe, pada bulan Januari 2018 sampai dengan bulan Februari 2018, dengan variabel penelitian ; Variabel bebas (independen) : Derajat penyakit hipertensi dan Variabel terikat (dependen) : Tingkat kecemasan pada kelompok lanjut usia Populasi adalah semua lanjut usia yang datang untuk berobat ke Puskesmas Kahakitang kecamatan Tatoareng yang berjumlah 67 orang menggunakan Total sampling sebanyak 67 responden, dengan kriteria inklusi, lansia umur 45-90 tahun keatas yang terdiagnosa penyakit hipertensi dan dapat melakukan aktifitas sehari-hari, kriteria ekslusi, lansia dengan riwayat penyakit hipertensi tetapi pada saat penelitian tidak hipertensi, tidak berada ditempat saat penelitian dan tidak bersedia jadi responden.

Penelitian menggunakan kuesioner dan pengukuran tekanan darah. Untuk mengetahui tingkat kecemasan pada lanjut usia menggunakan kuesioner GAS (Geriatric Anxiety Scale) terdiri dari 30 pernyataan tetapi yang hanya diteliti 25 pertanyaan, 5 pertanyaan untuk membantu dokter mengidentifikasi responden.

Cara mengisi setiap pernyataan. diberi nilai 0 (tidak ada gejala sama sekali), nilai 1 kadangkadang ( $1-2$ kali dalam seminggu) nilai 2 seringkali ( $3-5$ kali dalam seminggu), nilai 3 sepanjang waktu (6-7 kali dalam seminggu). Rentang penilaian skor $0-13$ (tidak ada 
kecemasan), 14-24 (kecemasan ringan), 2549 (kecemasan sedang), 50-75 (kecemasan berat). Untuk mengetahui penyakit hipertensi pada lanjut usia dilakukan pengukuran tekanan darah dengan menggunakan stetoskop dan tensimeter air raksa merek GEA, hasil penilaian didapatkan melalui pengukuran dengan rentang ringan Sistolik 140-159 mmHg Diastolik 90-99 $\mathrm{mmHg}$, sedang Sistolik 160-169 mmHg Diastolik 100$109 \mathrm{mmHg}$, berat Sistolik $\geq 180 \mathrm{mmHg}$ Diastolik $\geq 110 \mathrm{mmHg}$ yang diukur langsung oleh peneliti.

\section{Analisa Data}

1. Analisa Univariat

Dalam penelitian ini menguji setiap variabel dan disajikan dalam bentuk tabel antara lain umur, jenis kelamin, tingkat kecemasan, dan penyakit hipertensi pada lanjut usia.
2. Analisa Bivariat

Analisa yang dilakukan terhadap variabel dependen dan variabel independen yang diduga berhubungan atau berkolerasi (Notoatmojo 2012), Analisa ini menggunakan rumus statistik chi-square $\left(\mathrm{X}^{2}\right)$, dengan derajat kemaknaan $(\alpha)<$ 0,05 , dan tingkat siginifikan $>95 \%$ dengan rumus :

$$
X^{2}: \Sigma \frac{(f o-f e)^{2}}{F e}
$$

Keterangan :

$\mathrm{X}^{2}=$ harga nilai chi-square

$F O=$ frekuensi observasi

$F e=$ frekuensi harapan (Alimul, 2007)

Dimana :

a. Jika $X^{2}$ hitung $<X^{2}$ rabel, maka ada hubungan yang bermakna antara variabel yang diamati

b. Jika $X^{2}$ hitung $>X^{2}$ rabel, maka tidak ada hubungan yang bermakna antara variabel yang diamati.

\section{HASIL PENELITIAN DAN PEMBAHASAN}

\section{A. Hasil}

\section{Hasil Penelitian Univariat \\ Karakteristik Responden}

Tabel 4. Distribusi Frekuensi Kelompok Lanjut Usia yang Menderita Derajat Penyakit Hipertensi Menurut WHO

\begin{tabular}{lccc}
\hline No & Umur & Frekuensi & Persen (\%) \\
\hline 1. & $45-59$ & 25 & 37,31 \\
2. & $60-74$ & 35 & 52,25 \\
3. & $75-90$ & 7 & 10,44 \\
\hline & Total & 67 & 100 \\
\hline
\end{tabular}

Tabel ini menunjukan penderita penyakit hipertensi tertinggi pada kelompok lanjut usia umur 60 - 74 tahun berjumlah 35 orang ( 52 , $25 \%)$ 
Tabel 5. Distribusi Frekuensi Kelompok Lanjut Usia Yang Menderita Derajat Penyakit Hipertensi Menurut Jenis Kelamin

\begin{tabular}{cccc}
\hline No & Jenis Kelamin & Frekuensi & Persen (\%) \\
\hline $\mathbf{1 .}$ & Laki-Laki & 8 & 11.94 \\
$\mathbf{2 .}$ & Perempuan & 59 & 88,06 \\
\hline & Total & 67 & 100 \\
\hline
\end{tabular}

Pada tabel ditemukan jumlah terbanyak penderita hipertensi pada lanjut usia

dengan jenis kelamin perempuan sebanyak 59 orang $(88,06 \%)$

Tabel 6. Distribusi Frekuensi Kelompok Lanjut Usia Yang Menderita Derajat Penyakit Hipertensi Menurut Pendidikan

\begin{tabular}{cccc}
\hline No & Pendidikan & Frekuensi & Persen (\%) \\
\hline 1. & SD & 52 & 77,61 \\
2. & SMP & 6 & 8,96 \\
3. & SMA & 3 & 4,47 \\
4. & S1 & 6 & 8,96 \\
\hline & Total & 67 & 100 \\
\hline
\end{tabular}

Tabel ini ditemukan jumlah tertinggi penderita hipertensi pada lanjut usia dengan Pendidikan terakhir SD sebanyak
52 orang $(77,61 \%)$, sedangkan yang terendah tingkat Pendidikan terakhir SMA sebanyak 3 orang $(4,47 \%)$.

Tabel 7. Distribusi Frekuensi Kelompok Lanjut Usia Yang Menderita Derajat Penyakit Hipertensi Menurut Pekerjaan

\begin{tabular}{cccc}
\hline No & Pekerjaan & Frekuensi & Persen (\%) \\
\hline $\mathbf{1 .}$ & IRT & 54 & 80,60 \\
$\mathbf{2 .}$ & Wiraswasta & 2 & 3 \\
$\mathbf{3 .}$ & Tukang & 5 & 7,46 \\
$\mathbf{4 .}$ & Guru & 3 & 4,47 \\
$\mathbf{5 .}$ & Pensiunan & 3 & 4,47 \\
\hline & Total & 67 & 100 \\
\hline
\end{tabular}

Berdasarkan frekuensi pekerjaan jumlah tertinggi penderita hipertensi pada lanjut usia dengan pekerjaan IRT sebanyak 54 orang $(80,60 \%)$, sedangkan yang terendah pekerjaan sebagai Wiraswasta sebanyak 2 orang $(3 \%)$.

\section{Derajat Penyakit Hipertensi.}

Tabel 8. Distribusi Derajat Penyakit Hipertensi Pada Kelompok Lanjut Usia

\begin{tabular}{ccccccc}
\hline No & $\begin{array}{c}\text { Derajat Penyakit } \\
\text { Hipertensi }\end{array}$ & \multicolumn{3}{c}{ Kelompok Umur } & Frekuensi & Persen \\
\cline { 3 - 5 } & $45-59$ & $60-74$ & $75-90$ & & $(\%)$ \\
\hline $\mathbf{1}$ & Ringan & 10 & 12 & 2 & 24 & 36 \\
$\mathbf{2}$ & Sedang & 9 & 8 & 2 & 19 & 28 \\
$\mathbf{3}$ & Berat & 6 & 15 & 3 & 24 & 36 \\
\hline & Total & 25 & 35 & 7 & 67 & 100 \\
\hline
\end{tabular}

Pada tabel ini ditemukan yang tertinggi jumlah 24 orang $(36 \%)$ berada pada tingkat hipertensi ringan dan berat, sedangkan yang terendah dengan jumlah 19 orang $(28 \%)$ berada pada tingkat hipertensi sedang. 


\section{Tingkat Kecemasan}

Tabel 9. Distribusi Tingkat Kecemasan Pada Kelompok Lanjut Usia

\begin{tabular}{|c|c|c|c|c|c|c|}
\hline \multirow[t]{2}{*}{ No } & \multirow[t]{2}{*}{ Tingkat Kecemasan } & \multicolumn{3}{|c|}{ Kelompok Umur } & \multirow[t]{2}{*}{ Frekuensi } & \multirow{2}{*}{$\begin{array}{c}\text { Persen } \\
\text { (\%) }\end{array}$} \\
\hline & & $45-59$ & $60-74$ & $75-90$ & & \\
\hline 1 & Ringan & 8 & 11 & 2 & 21 & 31,34 \\
\hline 2 & Sedang & 13 & 14 & 3 & 30 & 44,78 \\
\hline 3 & Berat & 4 & 10 & 2 & 16 & 23,88 \\
\hline & Total & 25 & 35 & 7 & 67 & 100 \\
\hline
\end{tabular}

Tabel diatas ditemukan yang tertinggi 30 orang $(44,78 \%)$ pada tingkat kecemasan sedang dan yang terendah jumlah 16 orang $(23,88 \%)$ pada tingkat kecemasan berat.

\section{Hasil Penelitian Bivariat}

a Derajat Penyakit hipertensi dengan tingkat kecemasan pada Kelompok lanjut usia.

Tabel 10. Tabulasi Silang Antara Derajat Penyakit Hipertensi Dengan Tingkat Kecemasan Pada Kelompok Lanjut Usia

\begin{tabular}{ccccccc}
\hline Derajat & \multicolumn{3}{c}{ Tingkat kecemasan } & Total & Persen & p-value \\
\cline { 2 - 6 } $\begin{array}{c}\text { Penyakit } \\
\text { Hipertensi }\end{array}$ & Ringan & sedang & berat & & & \\
\hline Ringan & 17 & 7 & 0 & 24 & $36 \%$ & \\
Sedang & 4 & 14 & 1 & 19 & $28 \%$ & 0,000 \\
Berat & 0 & 9 & 15 & 24 & $36 \%$ & \\
\hline Total & 21 & 30 & 16 & 67 & $100 \%$ & \\
\hline
\end{tabular}

Dari tabel diatas menunjukan tabulasi silang antara variabel derajat penyakit hipertensi dan tingkat kecemasan pada kelompok lanjut usia, ternyata dari 24 lanjut usia dengan hipertensi ringan terdapat $17(70,8 \%)$ lanjut usia dengan tingkat kecemasan ringan $7(29,2 \%)$ lanjut usia dengan tingkat kecemasan sedang. Dari 19 lanjut usia dengan hipertensi sedang terdapat $4(21,1 \%)$ lanjut usia dengan tingkat kecemasan ringan, 14 $(73,7 \%)$ lanjut usia dengan tingkat kecemasan sedang dan 1 (5,3\%) lanjut usia dengan tingkat kecemasan berat. Dari 24 lanjut usia dengan hipertensi berat terdapat $9(37,5 \%)$ lanjut usia dengan tingkat kecemasan sedang dan 15 (62,5\%) lanjut usia dengan tingkat kecemasan berat. Uji yang akan digunakan adalah uji chi-square (pearson chi-square).

Dari hasil uji pearson Chi-square didapat nilai $\mathrm{x}^{2}=48,719$ dengan $\mathrm{p}$ (asmp.sig) $=$ $0,000<0,05$ berarti bermakna, Jadi Ho ditolak dan $\mathrm{Ha}$ diterima. $\mathrm{Hal}$ ini menunjukan bahwa ada hubungan yang bermakna antara penyakit hipertensi dengan tingkat kecemasan pada lanjut usia Di Wilayah Kerja Puskesmas Kahakitang.

\section{B. Pembahasan}

\section{Analisa Univariat}

a. Umur Responden.

Berdasarkan hasil penelitian di Wilayah Kerja Puskesmas Kahakitang Kecamatan Tatoareng, dari 67 responden yang berumur 45-90 tahun keatas mengalami hipertensi ringan 24 orang, hipertensi sedang 19 orang dan hipertensi berat 24 orang dengan total lanjut usia yang menjadi responden 67 orang. Menurut Maryan E, dkk (2010), dalam perkembangan lanjut usia penurunan fungsi tubuh akan banyak terjadi. Penurunan fungsi tubuh pada lansia diakibatkan karena proses penuaan. Proses penuaan merupakan proses yang mengakibatkan perubahan-perubahan meliputi perubahan fisik, psikologis, dan psikososial. Pada perubahan fisiologis terjadi penurunan sistem kekebalan tubuh dalam menghadapi gangguan dari dalam maupun luar tubuh, salah satu gangguan kesehatan yang paling banyak dialami pada lansia adalah pada sistem kardiovaskuler dimana terjadi penyempitan pada pembuluh darah akibatnya aliran darah terganggu sehingga memicu peningkatan tekanan darah. Menurut peneliti semakin tinggi umur seseorang maka semakin beresiko 
terkena berbagai macam penyakit baik dari dalam tubuh maupun dari luar tubuh.

b. Jenis Kelamin.

Berdasarkan frekuensi jenis kelamin menunjukan bahwa dari 67 responden terbanyak penderita hipertensi dengan jenis kelamin wanita 59 orang $(88,06 \%)$. Hipertensi atau tekanan darah lebih banyak menyerang wanita pada usia setelah 55 tahun, sekitar $60 \%$ penderita hipertensi adalah wanita. Hal ini berkaitan dengan perubahan hormon setelah menopause (Marliani, 2007). Wanita yang belum mengalami menopause dilindungi oleh hormone estrogen yang berperan dalam meningkatkan kadar High Density Lipoprotein (HDL). Kadar kolesterol HDL yang tinggi merupakan faktor pelindung dalam mencegah terjadinya proses aterosklerosis. Efek perlindungan ekstrogen dianggap sebagai penjelasan adanya imunitas wanita pada usia premenopause (Anggraini, 2009). Menurut peneliti hipertensi lebih sering terjadi pada wanita karna faktor stress yang dialami oleh wanita membuat wanita lebih rentan terkena hipertensi.

c. Pendidikan

Tingkat Pendidikan responden yang memiliki penyakit hipertensi yang paling banyak adalah SD berjumlah 52 orang $(77,61 \%)$ ini menunjukan dari segi pendidikan sebagian responden sangat kurang. Pendidikan yang kurang mempengaruhi ilmu yang didapat sehingga proses penyampain informasi kesehatan sangat kurang, hal ini didukung oleh pendapat Redja M. (dalam sulistiawan, 2008) Pendidikan adalah segala pengalaman belajar yang berlangsung dalam lingkungan dan sepanjang hidup serta segala situasi hidup yang mempengaruhi pertumbuhan individu. Menurut peneliti pendidikan sangat penting karna dengan pendidikan dapat menciptakan seseorang yang berkarakter dan berkualitas dalam mencapai cita-cita yang diharapkan.

d. Pekerjaan.

Frekuensi pekerjaan menunjuk-an bahwa pekerjaan responden terbanyak adalah IRT berjumlah 54 lanjut usia $(80,60 \%)$, dikarenakan pekerjaan berhubungan dengan status sosial ekonomi atau pendapatan keluarga yang berpengaruh dalam pemanfaatan pelayanan kesehatan yang ada. Menurut Lodahl \& Kejner dalam Aryaningtyas \& suharti (2013). Pekerjaan didefinisikan sebagai sejauh mana seseorang mengidentifikasi secara psikologis dengan pekerjaanya atau pentingnya pekerjaan dalam citra diri individu. Menurut peneliti pekerjaan sangat penting dalam mengembangkan ekonomi yang ada karna dengan pekerjaan yang baik maka dapat memenuhi kebutuhan hidup seseorang atau keluarga lebih baik lagi.

e. Derajat Penyakit Hipertensi

Penyakit hipertensi yang ditemukan pada saat penelitian di Wilayah Kerja Puskesmas Kahakitang Kecamatan Tatoareng hasil penelitian menunjukan banyak masyarakat menderita hipertensi ringan dan berat, hal ini berkaitan dengan usia dimana semakin tinggi usia seseorang semakin tinggi tekanan darahnya, jadi orang yang lebih tua cenderung mempunyai tekanan darah yang tinggi dibanding dengan yang berusia lebih muda, selain usia yang semakin tinggi faktor genetik dan pola hidup yang tidak sehat seperti masyarakat sering mengkonsumsi ikan asin yang berlebihan juga menyebabkan tekanan darah meningkat. Penelitian ini sejalan dengan penelitian Siwu Cresendi (2014) ada hubungan yang signifikan antara penyakit hipertensi dengan tingkat kecemasan pada lanjut usia di Wilayah Kerja Puskesmas Minanga Kecamatan Malalayang.

Penelitian ini menunjukan bahwa penyakit hipertensi terjadi karena pola konsumsi makanan yang tidak teratur dan stress yang yang dialami oleh lanjut usia. Menurut peneliti hipertensi terjadi karna pola konsumsi makanan yang tidak teratur. Budaya yang dianut serta stress yang dialami oleh lanjut usia.

f. Tingkat Kecemasan

Berdasarkan frekuensi tingkat kecemasan, didapat bahwa dari 67 sampel penderita hipertensi menunjukan angka tertinggi pada penderita hipertensi tingkat kecemasan sedang berjumlah 30 lanjut usia $(44,78)$.

Hasil penelitian tersebut menunjukan bahwa sebagian besar responden penderita hipertensi di Wilayah Kerja Puskesmas Kahakitang Kecamatan Tatoareng berada pada tingkat kecemasan sedang, menurut Maryam (2008) pada usia lanjut kecemasan akan kematian menjadi masalah psikologis yang penting pada lanjut usia, khususnya 
lanjut usia yang mengalami penyakit kronis.

\section{Analisa Bivariat}

Berdasarkan tabulasi silang antara variabel derajat penyakit hipertensi dan tingkat kecemasan pada kelompok lanjut usia, ternyata dari 24 lanjut usia dengan hipertensi ringan terdapat $17(70,8 \%)$ lanjut usia dengan tingkat kecemasan ringan dan $7(29,2 \%)$ lanjut usia dengan tingkat kecemasan sedang. Dari 19 lanjut usia dengan hipertensi sedang terdapat $4(21,1 \%)$ lanjut usia dengan tingkat kecemasan ringan, 14 (73,7\%) lanjut usia dengan tingkat kecemasan sedang dan 1 $(5,3 \%)$ lanjut usia dengan tingkat kecemasan berat. Dari 24 lanjut usia dengan hipertensi berat terdapat $9(37,5 \%)$ lanjut usia dengan tingkat kecemasan sedang dan 15 (62,5\%) lanjut usia dengan tingkat kecemasan berat.

Dari hasil uji pearson Chi-square didapat nilai $x^{2}=48,719$ dengan $p$ (asmp.sig) $=0,000<$ 0,05 berarti bermakna, Jadi Ho ditolak dan $\mathrm{Ha}$ diterima. Hal ini menunjukan bahwa ada hubungan yang bermakna antara derajat penyakit hipertensi dengan tingkat kecemasan pada kelompok lanjut usia Di Wilayah Kerja Puskesmas Kahakitang. Penelitian yang saya lakukan juga memiliki kesamaan dengan penelitian yang dilakukan Laksita Dwi Indra (2016). Mengatakan ada Hubungan lama penyakit hipertensi dengan tingkat kecemasan pada lansia Di Desa Praon Nusukan Surakarta dalam penelitian ini menjelaskan bahwa semakin lama mengalami hipertensi semakin tinggi tingkat kecemasan yang akan dialami responden. Siwu Cresendi (2014). Mengatakan ada Hubungan penyakit hipertensi dengan tingkat kecemasan pada lanjut usia Di Wilayah Kerja Puskesmas Minanga Kecamatan Malalayang dalam penelitian ini menjelaskan hipertensi terjadi karena faktor pola makan yang tidak teratur dan tinggi garam serta faktor stress yang sering dialami oleh lanjut usia. Penelitian Kadek Devi Pramana. Okatiranti dan Tita Puspita Ninggrum (2016). Mengatakan Ada Hubungan antara tingkat kecemasan dengan kejadian hipertensi Di Panti Sosial Tresna Werdha Senjarawi Bandung dalam penelitian ini menjelaskan bahwa salah satu factor resiko terjadinya hipertensi adalah kecemasan, kecemasan disebabkan karena berbagai keadaan seperti khawatir, gelisah, takut dan tidak tentram.. Penelitian Uswandari Dian Baiq (2017). Mengatakan Ada Hubungan antara kecemasan dengan kejadian hipertensi pada lansia Di Panti Sosial Tresna werdha dalam penelitian ini menjelaskan bahwa kecemasan kecemasan dapat mempengaruhi hipertensi pada lanjut usia.. Sehingga menurut peneliti hipertensi terjadi karna pola makan yang tidak teratur dimana sering mengkonsumsi makanan yang tinggi garam, stress yang dialami oleh lanjut usia serta budaya yang dianut.

$\mathrm{Hal}$ ini didukung oleh pendapat Lingga (2012). Bahwa pertambahan usia menyebabkan tekanan darah meningkat dan berpotensi mengalami hipertensi. Penyakit kronis seperti hipertensi dapat menyebabkan stress psikologis yang dapat berkelanjutan menjadi kecemasan, Hawari (2007). Sebagaimana pendapat Elina Raharisti Rufaidah, (2009). Kecemasan yang terjadi pada lanjut usia terjadi karena beberapa faktor seperti selalu memikirkan penyakit yang dideritanya, kendala ekonomi dan waktu berkumpul dengan keluarga sangat sedikit dikarenakan anakanaknya tidak berada satu rumah atau tinggal di luar kota. Dari hasil penelitian ini sesuai dengan teori yang ada menunjukan bahwa lanjut usia yang berada $\mathrm{Di}$ Kampung Behongang Sowaeng, Kampung Dalako Bembanehe, Kampung Taleko Batusaiki Di Wilayah Kerja Puskesmas Kahakitang Kecamatan Tatoareng yang menderita penyakit hipertensi rata-rata mengalami kecemasan.

\section{KESIMPULAN DAN SARAN}

A. Kesimpulan

Dari hasil penelitian mengenai "Hubungan Derajat Penyakit Hipertensi Dengan Tingkat Kecemasan Pada Kelompok Lanjut Usia Di Wilayah Kerja Puskesmas Kahakitang Kecamatan Tatoareng", maka dapat ditarik kesimpulan penderita derajat penyakit hipertensi pada kelompok lanjut usia yang berumur 45-90 tahun keatas yang menderita hipertensi 24 orang (36\%) masing-masing berada pada hipertensi ringan dan berat dengan tingkat kecemasan sedang 30 lanjut usia $(44,78 \%)$ sehingga pada hasil penelitian yang di analisis melalui uji chi-square ditemukan $p=0,000$ yang lebih kecil dari $\alpha=$ 0,05 yang berarti bahwa ada hubungan yang sangat bermakna pada derajat penyakit hipertensi dengan tingkat kecemasan pada kelompok lanjut usia Di Wilayah Kerja Puskesmas Kahakitang Kecamatan Tatoareng.

B. Saran

Bagi Petugas Kesehatan Di Wilayah Kerja Puskesmas Kahakitang agar mengajurkan lanjut usia untuk tetap mengontrol tekanan darah dan menjaga keadaan psikologisnya, 
meningkatkan pelayanan promosi kesehatan pada kelompok lanjut usia, mempertahankan pemberdayaan kelompok lanjut usia, melatih kader-kader kelompok lanjut usia dalam peningkatan kelompok lanjut usia.

\section{DAFTAR PUSTAKA}

Anggraini, A. D, Waren, S. Situmoran, E, Asputra, H \& Siahaan, SS. (2009). Penelitian Faktor-faktor yang berhubungan dengan kejadian hipertensi pada pasien yang berobat di Poliklinik Dewasa Puskesmas Bangkinang Periode Januari sampai Juni 2008.

Aryaningtyas, Aurelia T., (2013), Keterlibatan Kerja Sebagai Pemediasi Pengaruh Kepribadian Proaktif dan Persepsi Dukungan Organizational terhadap Kepuasan Kerja, Program Studi Bina wisata, Sekolah Tinggi Ilmu Ekonomi Pariwisata Indonesia (STIEPARI) Semarang. Jurnal JMK,15 (NO.1), Maret 2013, 23-32, ISSN 14411-1438

Aziz. A. H. (2007), Metode Penelitian dan Teknik Analisis Data, Salemba Medika. Jakarta.

Azizah, L.M., (2011), Keperawatan lanjut usia, Graha ilmu, Yogyakarta.

Badan Pusat Statistik, (2013), Statistik Penduduk Lanjut Usia 2013, Jakarta

Eka, R. A., (2010), Penelitian Hubungan tingkat kecemasan dengan keberhasilan memberikan obat melalui infus pada mahasiswa FIK UI Angkatan 2010.

Fitri, F \& Julianty, W., (2007). Psikologi Abnormal Klinis Dewasa. Universitas Indonesia Press, Jakarta.

Guyton, AC. (2008). Buku Ajar Fisiologi Kedokteran, Alih Bahasa dr. Irawati Setiawan, dr, LMA Ken Ariata Tengadi dan dr. Alex Santoso, Buku Kedokteran EGC, Jakarta.

Hawari, D. (2007). Manajemen Stres cemas dan depresi, Balai Penerbit FKUI, Jakarta.

Kadek D. P., Okatiranti dan Tirta P. N. (2016), Hubungan tingkat kecemasan dengan kejadian hipertensi di Pandi Sosial Tresna Werdha Senjarawi Bandung, Jurnal IImu Keperawatan, Vol. IV No. 2 September 2016.

Laksita D. I., (2016), Penelitian Hubungan lama menderita penyakit hipertensi dengan tingkat kecemasan pada lansia di Desa Praon Nusukan Surakarta.

LeMone, P. Burke, K. M. \& Bauldoff, G. (2013). Medical Surgical Nursing : Critical Thinking In Patient Care. United Kingdom

Lingga, L. (2012), Bebas Hipertensi Tanpa Obat, Agromedia Pustaka, Jakarta.

Mudyahardjo, Redja., (2008), Pengantar Pendidikan Sebuah Studi Awal Tentang Dasar-dasar Pendidikan Pada Umumnya dan Pendidikan di Indonesia, Raja Grafindo Persada, Jakarta.

Notoatmodjo. S., (2010), Metode Penelitian Kesehatan, Rineke Cipta, Jakarta.

Responiel H., (2013), Hipertensi menurut WHO. Available from https://www.slideshare.net/ResponielHala wa/hipertensi-tekanan-darah-tinggi-2016 Accessed 5 Januari 2017.

Riskesdas, (2013), Prevelensi Hipertensi di Indonesia. Available from www.depkes.go.id, Accessed 12 Maret 2016.

Rosta, J., (2011)., Penelitian Hubungan Asupan Energi, Protein, Lemak dengan Status Gizi dan Tekanan Darah Geriatri di Panti wredha Surakarta.

Rufaidhah, Elina R., (2009). Efektivitas terapi kognitif perilaku terhadap penurunan tingkat kecemasan pada penderita asma di Surakarta. Universitas Gadjah Mada. Yogyakarta.

Siwu C., (2014)., Penelitian Hubungan penyakit hipertensi dengan tingkat kecemasan pada lanjut usia di Wilayah Kerja Puskesmas Minanga Kecamatan Malalayang.

Uswandari D. B., (2017), Penelitian Hubungan antara kecemasan dengan kejadian hipertensi pada lansia di Panti Sosial Tresna Werdha.

Webber, M.A, dkk., (2014), Practice Guidelines for the Management of Hypertension in the Community: A Statement by the American Society of Hypertension and the International Society of Hypertension. Journal of Clinical Hypertension (Greenwich, Conn.).

Wijaya, A. S. dan Putri, Y. M., (2013), Keperawatan Medikal Bedah 1. Nuha Medika. Yogyakarta.

World Health Organization (WHO, (2013), Peningkatan Proporsi Lansia. 